\title{
Understanding the ERP System Use in Budgeting
}

\author{
Wipawee Uppatumwichian \\ Department of Informatics, Lund University, Ole Römers väg 6, 22363 Lund, Sweden \\ wipawee.uppatumwichian@ics.lu.se
}

\begin{abstract}
This paper investigates the enterprise resource planning (ERP) system use in budgeting in order to explain how and why ERP systems are used or not used in budgeting practices. Budgeting is considered as a social phenomenon which requires flexibility for decision-making and integration for management controls. The analysis at the activity levels, guided by the concept of 'conflict' in structuration theory (ST), suggests that ERP systems impede flexibility in decision-making. However, the systems have the potential to facilitate integration in management controls. The analysis at the structural level, guided by the concept of 'contradiction' in ST, concludes that the ERP systems are not widely used in budgeting. This is because the systems support the integration function alone while budgeting assumes both roles. This paper offers the ERP system non-use explanation from an ulitarian perspective. Additionally, it calls for solutions to improve ERP use especially for the integration function.
\end{abstract}

Keywords: structuration theory, budgeting, ERP system, IS use.

\section{Introduction}

The advance in information system (IS) technologies has promised many improved benefits to organisations [1, 2]. However such improvements are often hindered by unwillingness to accept new IS technologies [3,4]. This results in IS technology nonuse [5] and/or workaround [6, 7] and, inevitably moderate business benefits. For this reason, a traditional IS use research has been well-established in the discipline [8] to investigate how and why users use or not use certain IS technologies.

In the field of accounting information system (AIS), previous research has indicated that there is a limited amount of research as well as understanding on the use of enterprise resource planning (ERP) systems to support management accounting practices [9-12]. Up to now, the available research results conclude that most organisations have not yet embraced the powerful capacity of the ERP systems to support the management accounting function [4, 13, 14]. Many studies have reported a consistent limited ERP use in management accounting function using data from many countries across the globe such as Egypt [15], Australia [16], Finland [4, 17-19] and Denmark [20]. Several researchers have in particular called for more research contributions on the ERP system use in management accounting context, and especially on how the systems might be used to support the two key functions in 
manegement accounting: decision-making and management control functions [10, 12, 21]. This paper responds to that call by uncovering the ERP systems use in budgeting. In relation to other management accounting activities, budgeting is considered to be the most suitable social phenomenon under investigation. This is because budgeting is a longstanding control procedure [22] which continues to soar in popularity among modern organisations [23]. In addition, it assumes the dual roles of decision-making and management control [24].

Budgeting is considered as a process undertaken to achieve a quantitative statement for a defined time period [25]. A budget cycle can be said to cover activities such as (1) budget construction, (2) consolidation, (3) monitoring and (4) reporting. The levers of control (LOC) framework [26] suggests that budgeting can be used interactively for decision-making and diagnostically for management control. This is in line with modern budgeting literature [24, 27] whose interpretation is that budgeting assumes the dual roles. However, the degree of combination between these two roles varies according to management's judgements in specific situations [26]. This dual role requires budgeting to be more flexible for decision-making yet integrative for management control [28].

Given the research gaps addressed and the flexible yet integrative roles of budgeting, this paper seeks to uncover how the ERP systems are used in budgeting as well as to explain why the ERP systems are used or not used in budgeting.

This paper proceeds as follows. The next section provides a literature review in the ERP system use literature with regard to the integration and flexibility domains. Section 3 discusses the concepts of conflict and contradiction in structuration theory (ST) which is the main theory used. After that, section 4 deliberates on the research method and case companies contained in this study. Subsequently, section 5 proceeds to data analysis based on the conflict and contradiction concepts in ST in order to explain how and why ERP systems are used or not used in budgeting. Section 6 ends this paper with conclusions and research implications.

\section{The ERP Literature Review on Flexibility and Integration}

This section reviews ERP literatures based on the integration and flexibility domains as it has been previously suggested that budgeting possesses these dual roles. It starts out with a brief discussion on what the ERP system is and its relation to accounting. Later it proceeds to discuss about incompatible conclusions in the literature about how the ERP system can be used to promote flexibility and integration.

The ERP system, in essence, is an integrated cross-functional system containing many selectable software modules which span to support numerous business functions that a typical organisation might have such as accounting and finance, human resources, and sales and distributions [12]. The system can be considered as a reference model which segments organisations into diverse yet related functions through a centralised database [29]. The ERP system mandates a rigid business model which enforces underlying data structure, process model as well as organisational 
structure [30] in order to achieve an ultimate integration between business operation and IS technology [31].

The ERP system has become a main research interest within the IS discipline as well as its sister discipline, the AIS research, since the inception of this system in the early 1990s [4, 12]. Indeed, it can be said that AIS gives rise to the modern ERP system because accounting is one of the early business operations that IS technology is employed to hasten the process [32]. A research finding [13] posits that the ERP systems require implementing organisations to set up the systems according to either 'accounting' or 'logistic' modes which forms a different control locus in organisations. Such indication strongly supports the prevailing relationship that accounting has in connection to the modern ERP system.

In relation to the flexibility domain, research to date has provided a contradictory conclusion on the relationship between the ERP system and flexibility. One research stream considers the ERP system to impose a stabilising effect on organisations because of the lack of flexibility in relation to changing business conditions $[7,16,17$, 20, 33, 34]. Akkermans et al. [35], for example, report that leading IT executives perceive the ERP system as a hindrance to strategic business initiatives. The ERP system is said to have low system flexibility which does not correspond to the changing networking organisation mode. This line of research concludes that a lack of flexibility in ERP system can post a direct risk to organisations because the ERP system reference model is not suitable to business processes [34, 36]. In addition, the lack of flexibility results in two possible lines of actions from users: (1) actions in the form of inaction, that is, a passive resistance not to use the ERP systems [5], or (2) actions to reinvent the systems or a workaround [7]. The other stream of research maintains that ERP system implementation improve flexibility in organisations [2, 3739]. Shang and Seddon [2], for example, propose that the ERP system contributes to increased flexibility in organisational strategies. This is because a modular IT infrastructure in the ERP system allows organisations to cherry pick modules which support their current business initiatives. In the same line, Brazel and Dang [37] posit that ERP implementation allows more organisational flexibility to generate financial reports. Cadili and Whitley [39] support this view to a certain extent as they insert that the flexibility of an ERP system tends to decrease as the system grows in size and complication.

With regard to the integration domain, a similar contradictory conclusion on the role of ERP to integration is presented in the literature. One stream of research posits that the reference model embedded in the ERP system [29], which enforces a strict data definition across organisational units through a single database, enables integration and control [2, 14, 19, 37, 38]. Some of the benefits mentioned in the literature after an ERP implementation are: reporting capability [37], information quality [40], decision-making [38] and strategic alliance [2]. Another stream of research tends to put a serious criticism toward the view that ERP implementation will enable organisational integration. Quattrone and Hopper [41], for example, argue that the ERP system is at best a belief that activities can be integrated by making transactions visible and homogenous. Dechow and Mouritsen [13] explicitly support this view by indicating that: "[The] ERP systems do not define what integration is and 
how it is to be developed". They argue that it is not possible to manage integration around the ERP systems, or any other IS systems. Regularly, any other means of integration but IS is more fruitful for organisational integration and control, such as a lunch room observation. In many cases, it is argued that integration can only be achieved through a willingness to throw away some data and integrate less information [31].

\section{Theoretical Background}

A review of IS use research [8] has indicated that there are three main explanatory views which are widely used to explain IS use research. First the ulitarian view holds that users are rational in their choice of system use. This stream of research often employs a technology acceptance model [3] or a media richness theory [42] to explain system use. Second the social influence view deems that social mechanisms are of importance in enforcing system use in particular social contexts [43]. The third and the last contingency view [44] explains that people decide to use or not to use systems through personal characteristics and situational factors. Factors such as behavioural control [6], as well as skills and recipient attributes [45] serve as explanations to system use/non-use.

Being aware about these theoretical alternatives in the literature, the author chooses to approach this research through the lens of ST. It is convinced that the theory has a potential to uncover ERP use based on the ulitarian view. ST is appealing to the ERP system use study because the flexible yet integrative roles of budgeting fit into the contradiction discussion in social sciences research. It has been discussed that most modern theories along with social practices represent contradictions in themselves [46]. Anthony Giddens, the founder of ST, explicitly supports the aforementioned argument. He writes: "don't look for the functions social practices fulfil, look for the contradiction they embody!" [47].

The heart of ST is an attempt to treat human actions and social structures as a duality rather than a dualism. To achieve this, Giddens bridges the two opposing philosophical views of functionalism and interpretivism. Functionalism holds that social structures are independent of human actions. Interpretivism, on the contrary, holds that social structures exist only in human minds. It is maintained that structures exist as human actors apply them. They are the medium and outcome of human interactions. ST is appealing to IS research because of its vast potential to uncover the interplay of people with technology [48, 49].

This paper focuses particularly on one element of ST, which is the concept of conflict and contradiction. According to Walsham [5], this concept is largely ignored in the literature as well as in the IS research. Giddens defines contradiction as "an opposition or disjunction of structural principles of social systems, where those principles operate in terms of each other but at the same time contravene one another" [47]. To supplement contradiction which occurs at the structural level, he conceptualises conflict, which is claimed to occur at the level of social practice. In his own words, conflict is a "struggle between actors or collectives expressed as definite 
social practices" [47]. Based on the original writing, Walsham [5] interprets conflicts as the real activity and contradiction as the potential basis for conflict which arises from structural contradictions.

This theorising has immediate application to the study of ERP systems use in budgeting. It is deemed that the flexibility (in decision-making) and integration (in management control) inherent in budgeting are the real activities that face business controllers in their daily operations with budgeting. Meanwhile, ERP systems and budgeting are treated as two different social structures [50] which form the potential basis for conflict due to the clash between these structures. The next section discusses the research method and the case organisations involved in this study.

\section{Research Method and Case Description}

This study employs an interpretative case study method according to Walsham [51]. The primary research design is a multiple case study [52] in which the researcher investigates a single phenomenon [53], namely the use of ERP systems in budgeting. This research design is based on rich empirical data [52, 54], therefore it tends to generate better explanation in respond to the initial research aim to describe and explain ERP system use in budgeting.

Eleven for-profit organisations from Thailand are included in this study. To be eligible for the study, these organisations meet the following three criteria. First they have installed and used an ERP system for finance and accounting functions for at least two years to ensure system maturity [55]. Second, they employ budgeting as the main management accounting control. Third they are listed on a stock exchange to ensure size and internal control consistency due to stock market regulations [12].

This research is designed with triangulation in mind [56] in order to improve the validity of research findings. Based on Denzin [57]'s triangulation typologies, the methodological triangulation is applied in this study. Interviews, which are the primary data collection method, are conducted with twenty-one business controllers in eleven profit-organisations in Thailand in autumn 2011. These interviews are conducted at interviewee's locations. Therefore data from several other sources such as internal documentations and system demonstrations are available to the researcher for the methodological triangulation purpose. The interview follows a semi-structured format which lasts for approximately one to two hours on average. Interview participants are business controllers who are directly responsible for budgeting as well as IS technologies within organisations. Interview participants are for example chief financial controller (CFO), accounting vice president, planning vice president, accounting policy vice president, management accounting manager, business analyst, and business intelligent manager. Appendix 1 provides an excerpt of the interview guide. All interview participants have been working for the current organisations for a considerable amount of time which ranges between two to twenty years. Therefore it is deemed that they are knowledgeable of the subject under investigation. All interviews are recorded, transcribed and analysed in Nvivo8 data analysis software. Coding is performed following the inductive coding technique [56] using a simple 
two-level theme; an open-ended general etic coding followed by a more specific emic coding in order to allow a maximum interwoven within data analysis. Appendix 2 provides an example of the coding process performed in this research.

With regard to the case companies, the organisations selected represent core industries of Thailand such as the energy industry (Cases A-C), the food industry (Cases D-G) and the automobile industry (Cases H and I). The energy group is the backbone of Thailand's energy production chain, which accounts for more than half of the country's energy demands. The food industry group includes business units of global food companies and Thai food conglomerates which export foods worldwide. The automobile industry group is directly involved in the production and distribution chains of the world's leading automobile brands. For the two remaining cases, Case J is a Thai business unit of a global household electronic appliance company. Case $\mathrm{K}$ is a Thai hospitality conglomerate which operates numerous five-star hotels and luxury serviced apartments throughout the Asia Pacific region. In terms of IS technologies, all of these companies employ both ERP and spreadsheets (SSs) for budgeting functions. However, some have access to additional BI applications. Some companies employ off-the-shelf BI solutions for budgeting purpose such as the Cognos BI systems. Nevertheless some companies choose to develop their own BI systems in collaboration with IS/IT consultants. This type of in-house BI is referred to as "own BI". Table 1 provides a clear description of each case organisation. The next section presents data analysis obtained from these organisations.

Table 1. Case company description

\begin{tabular}{clcccc}
\hline Case & \multicolumn{1}{c}{ Main Activities } & Owner & ERP & SSs & BI \\
\hline A & Power plant & Thai & SAP & Yes & Magnitude \\
B & Oil and Petrochemical & Thai & SAP & Yes & Cognos \\
C & Oil refinery & Thai & SAP & Yes & - \\
D & Frozen food processor & Thai & SAP & Yes & - \\
E & Drinks and dairy products & Foreign & SAP & Yes & Magnitude \\
F & Drinks & Foreign & SAP & Yes & Own BI \\
G & Agricultural products & Thai & BPCS & Yes & - \\
H & Truck & Foreign & SAP & Yes & - \\
I & Automobile parts & Thai & SAP & Yes & Own BI \\
J & Electronic appliances & Foreign & JDE & Yes & Own BI \\
K & Hotels and apartments & Thai & Oracle & Yes & IDeaS \\
\hline
\end{tabular}

\section{$5 \quad$ Analysis}

The analysis is presented based on the theoretical section presented earlier. It starts with the 'conflict' between (1) the ERP system and flexibility and (2) the ERP system and integration at the four budgeting activity levels. These two sections aim to explain how the ERP systems are used or not used in budgeting. Later on, the paper proceeds to discuss the 'contradiction' between the ERP system and budgeting at a 
structural level in order to suggest why the ERP system are used or not used to support budgeting activities.

\subsection{Conflict at the Activity Level: ERP System and Flexibility}

Flexibility, defined as business controllers' discretion to use IS technologies for budget-related decision-making [58], is needed throughout the budgeting process. Based on a normal budgeting cycle, there are two important activities in relation to the flexibility definition: (1) budget construction, and (2) budget reporting. These two activities require business controllers to construct a data model on an IS technology which takes into account the complex environmental conditions [27, 59] to determine the best possible alternatives.

In the first activity of budget construction, this process requires a high level of flexibility because budgets are typically constructed in response to specific activities and conditions presented in each business unit. The ERP system is not called upon for budget construction in any case company because of the following two reasons: (1) the technology is developed in a generic manner such that it cannot be used to support any specific budgeting process. The Vice President Information Technology in Case I mentions: "SAP [ERP] is too generic" for budgeting. [...] They [SAP ERP developers] have to develop something that perfectly fits with the nature of the business, but I know it is not easy to do because they have to deal with massive accounting codes and a complicated chart of accounts". This suggestion is similar to the reason indicated by the Financial Planning Manager in Case F who explains that her attempt to use an ERP system for budgeting was not successful because "SAP [ERP] has a limitation when it comes to revenue handling. It cannot handle any complicated revenue structure". (2) The technology is not flexible enough to accommodate changes in business conditions which are the keys to forecasting future business operations. The Central Accounting Manager in Case G suggests that the ERP system limits what business controllers can do with their budgeting procedures in connection with volatile environments. She explicitly mentions that: "our [budgeting] requirements change all the time. The ERP system is fixed; you get what the system is configured for. It is almost impossible to alter the system. Our Excel [spreadsheets] can do a lot more than the ERP system. For example, our ERP system does not contain competitor information. In Excel, I can just create another column and put it in".

In the second activity of budget reporting, all cases run basic financial accounting reports from the ERP systems, and then they further edit the reports to fit their managerial requirements and variance analysis in spreadsheets. The practice is also similar in Cases A, B and E, where the ERP systems are utilised for budget monitoring (see more discussion in the next section). For example, the Corporate Accounting Manager in Case D indicates how the ERP system is not flexible for reporting and how he works around it: "When I need to run a report from the ERP

\footnotetext{
${ }^{1}$ This italic shown in the original interview text represents the author's intention to emphasize certain information in the original interview text. This practice is used throughout the paper.
} 
system, I have to run many reports then I mix them all in Excel [spreadsheets] to get exactly what I want". The Business Intelligence Manager in Case K comments on why she sees that the ERP system is not flexible enough for variance analysis: "It is quite hard to analyse budgeting information in the ERP system. It is hard to make any sense out of it because everything is too standardised".

In summary, the empirical data suggests the ERP systems are not used to support the flexibility domain in budgeting since that there is a clear conflict between the ERP system and the flexibility required in budgeting activities. The ERP systems put limitations on what business controllers can or cannot do with regard to flexibility in budgeting. For example business controller cannot perform complicated business forecasting which is necessary for budget construction on the ERP system. This conflict is clearly addressed by the Financial Planning Manager in Case F who states: "The SAP [ERP] functions are not flexible enough [for budgeting] but it is quite good for [financial] accounting".

\subsection{Conflict at the Activity Level: ERP System and Integration}

Integration, defined as the adoption of IS technologies to standardise data definitions and structures across data sources [60], is needed for budget control. Based on a normal budgeting cycle, there are two important activities in relation to the definition of integration: (1) budget consolidation, and (2) budget monitoring. Various departmental budgets are consolidated together at an organisational level, which is subsequently used for comparison with actual operating results generated from financial accounting for monitoring purposes.

In the first activity of budget consolidation, none of the case companies is reported to be using the ERP system for this function. The majority of budgets are constructed and consolidated outside the main ERP system, typically in spreadsheets (except Case $\mathrm{B}$, which uses a mixture of spreadsheets and $\mathrm{BI}$ ). The $\mathrm{CFO}$ in Case $\mathrm{H}$ gives an overview of the company budgeting process: "We do budgeting and business planning processes on Excel [spreadsheets]. It is not only us that do it like this. All of the six [Southeast Asian] regional companies also follow this practice. Every company has to submit budgets on spreadsheets to the regional headquarters. The budget consolidation is also completed on spreadsheets". Regardless of a company's choice to bypass the ERP system for budget consolidation, all the case companies are able to use their ERP systems to prepare and consolidate financial statements for a financial accounting purpose at a specific company level, but not necessarily at a group level. These financial accounting statements will be used to support the second activity of budget monitoring.

In the second activity of budget monitoring, three case companies (Cases A, B and E) report that they use their ERP systems for budget monitoring purposes. The Planning Vice President in Case B mentions: "SAP [ERP] is more like a place which we put budgeting numbers into. We use it to control budgets. We prepare budgets outside the system but we put the final budget numbers into it for a controlling purpose so that we can track budget spending in relation to the purchasing function in SAP [ERP]". A similar use of the ERP systems is presented in Cases A and E, where 
budgets are loaded into SAP ERP Controlling (CO) and Project System (PS) modules for budget spending monitoring. Note that only the final budget numbers (after budget consolidation in spreadsheets) are loaded into the ERP system for a control purpose alone. The ERP system does not play a part in any budget construction processes in these three cases, as it is mentioned in the previous section that budget construction is entirely achieved outside the main ERP system.

In conclusion, the empirical data suggests that the ERP systems are not widely used to support the integration domain in budgeting. However the empirical data suggests that the ERP systems have the potential to support budget integration as it has been shown earlier that all case companies use the ERP system to prepare financial statements and some cases use the ERP systems to monitor budget spending/achievement. Regardless of the potential that the ERP systems offer, these companies have not widely used the ERP systems to support budgeting practice. Companies have yet to realise this hidden potential of the ERP system [18] to integrate currently separated financial accounting (e.g. financial statement preparation) and management accounting (e.g. budgeting) practices.

\subsection{Contradiction at the Structural Level}

Based on the discussions at the two activity levels presented in earlier sections, this section builds on the concept of contradiction in ST to explain how and why the ERP systems are used or not used in budgeting.

Budgeting as a social practice is deemed to operate in terms of flexibility and integration, while at the same time these contravene each other. It has been shown earlier that the four main budgeting activities in a typical budgeting cycle (budget construction, budget consolidation, budget monitoring and budget reporting) belong equally to both the integration and flexibility domains. With regards to the four budgeting activities, it has been shown that the four main budgeting remain outside the main ERP systems with an exception of the budget monitoring activity alone. In this activity, a minority of case companies use the ERP systems to support this work function. It is also noted that the ERP systems have the potential to consolidate budgeting information but it seems that companies have not yet decided to utilise this capability offered in the systems.

Explanations based on the ulitarian view through the conflict and contradiction concept in ST deem that the ERP systems are not used in the budgeting activities because the systems only have the capabilities to support the integration function alone. Compared with budgeting practice which needs flexibility in decision-making as well as integration in management control, the ERP systems are obviously not suitable to support budgeting. Figure 1 shows the overall discussion about the contradiction between the ERP systems and budgeting at a structural level. It explains the shifts in the roles of budgeting activities from flexibility in activity one, budget construction, to integration in activity two, budget consolidation, and so on. It also elaborates how the ERP systems can have the potential to support some particular activities (such as budget consolidation and budget monitoring) but not the others. 


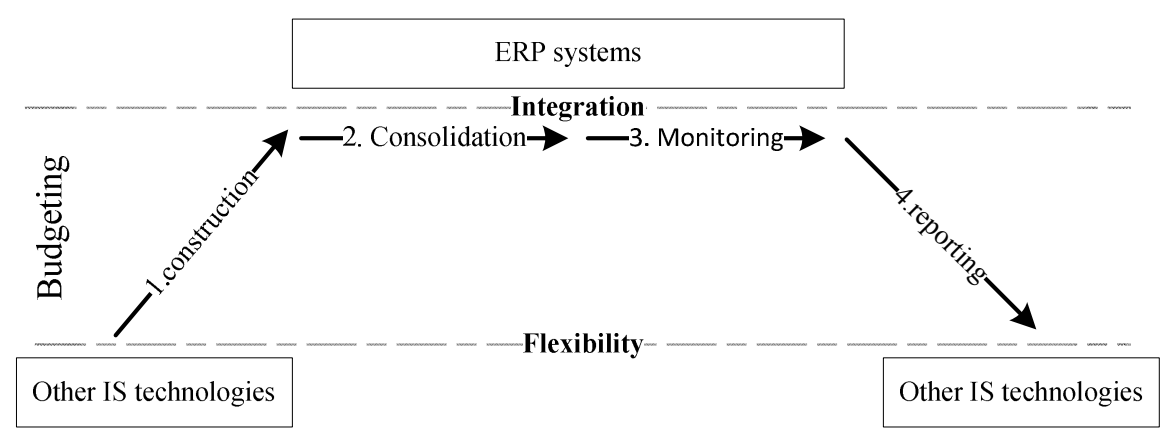

Fig. 1. Contradiction between budgeting and ERP system

So why do the ERP systems support the integration but not the flexibility in budgeting? Despite all the endlessly fancy claims made by numerous ERP vendors, the basic assumptions of the ERP system are a reference model which enforces underlying data, business process and organisational structure. The procedures described by the system must be strictly adhered to throughout organisational task executions [29]. Therefore it is hard or even impossible to alter the systems to change in response to new business requirements or circumstances because such change is contradictory to the most basic principle of the systems.

So how can we readdress the limitations of ERP systems to support the flexibility needs in budgeting? As Figure 1 explains, other types of IS technologies such as spreadsheets and business intelligence (BI) must be called upon to support the activities that the ERP systems cannot accommodate [61]. These technologies are built and designed from different assumptions from those of the ERP systems; therefore they can accommodate the flexibility in budgeting. These systems can be combined to support strategic moves made by top management according to the indication from the LOC framework [26].

\section{Conclusions and Implications}

This paper investigates how and why the ERP systems are used or not used in budgeting. It builds from the concepts of conflict and contradiction in ST, which is based on the ulitarian view of IS technology use perspective. Budgeting is treated as a social practice which portrays the two consecutive but contradictory roles of flexibility and integration. Using empirical data from eleven case companies in Thailand, the analysis at the activity level reveals that the ERP systems are not used to support the flexibility domain in budgeting because the systems impede business controllers to perform flexibility-related activities in budgeting, namely budget construction and budget reporting. The analysis on the integration-related budgeting function reveals that the ERP are not widely used to support the activities either. However it strongly suggests the system capability to support the integration function in budgeting as the systems are widely used to generate financial reports along with the evidence that some case companies are using the ERP systems for budget 
monitoring purpose. The analysis at the structuration level concludes why the ERP systems are not widely used to support budgeting. It is deemed that there is a contradictory relationship between the ERP systems and budgeting because the systems operate only in terms of integration, while the budgeting process assumes both roles. For this reason, other types of IS technologies such as spreadsheets and BI are called upon to accommodate tasks that cannot be supported in the main ERP systems.

This research result concurs with previous research conclusion that the ERP systems may post a flexibility issue to organisations because the systems cannot be tailored or changed in respond to business conditions or user requirements $[16,20,34$, 35]. Hence it does not support research findings which conclude the ERP systems promote flexibility in organisations [37]. In addition, it corresponds to previous findings which indicate that the ERP systems may assist integration in organisations $[2,14]$. At least, the ERP systems can support a company-wide data integration which is significant in accounting and management control but not necessary a companywide business process integration $[13,31]$.

The use of the ulitarian view to generate explanations for ERP system use/non-use is still somewhat limited. There are many aspects that the ulitarian view cannot capture. For example, the ulitarian view cannot provide an explanation as to why the ERP systems are not widely used to support the budget integration functions despite the system capabilities for financial consolidations and budget monitoring. This suggests that other views, such as the social view as well as the contingency view suggested in prior literature, are necessary in explaining the ERP system use/non-use. Therefore future IS use research should employ theories and insights from many perspectives to gain insights into the IS use/non-use phenomena.

The results presented in this study should be interpreted with a careful attention. Case study, by definition, makes no claims to be typical. The nature of case study is based upon studies of small, idiosyncratic and predominantly non-numerical sample set, therefore there is no way to establish the probability that the data can be generalised to the larger population. On the contrary, the hallmark of case study approach lies in theory-building [52] which can be transposed beyond the original sites of study.

The research offers two new insights to the IS research community. First, it explains the ERP system limited use explanation in budgeting from an ulitarian perspective. It holds that the ERP systems have the potential to support only half of the budgeting activities. Explicitly, the systems can support the integration in management control but not the flexibility in decision-making. Second, it shows that business controllers recognise such limitations imposed by the ERP systems and that they choose to rely on other IS technologies especially spreadsheets to accomplish their budgeting tasks. Spreadsheets use is problematic in itself, issues such as spreadsheets errors and frauds are well-documented in the literature. Therefore academia should look for solutions to improve professionally designed IS technologies (e.g., the ERP system or the BI) use in organisations and reduce spreadsheets reliance in budgeting as well as in other business activities. 
For practitioners, this research warns them to make informed decisions about IT/IS investments. ERP vendors often persuade prospective buyers to think that their systems are multipurpose. This research shows at least one of the many business functions in which the ERP systems do not excel. Thus any further IT/IS investments must be made with a serious consideration to the business function that needs support, as well the overall business strategies guiding the entire organisation.

\section{References}

1. Davenport, T.H.: Putting the enterprise into the enterprise system. Harvard Bus. Rev. 76, 121-131 (1998)

2. Shang, S., Seddon, P.B.: Assessing and managing the benefits of enterprise systems: the business manager's perspective. Information Systems Journal 12, 271-299 (2002)

3. Davis, F.D.: Perceived Usefulness, Perceived Ease of Use, and User Acceptance of Information Technology. MIS Quarterly 13, 319-340 (1989)

4. Granlund, M., Malmi, T.: Moderate impact of ERPS on management accounting: a lag or permanent outcome? Management Accounting Research 13, 299-321 (2002)

5. Walsham, G.: Cross-Cultural Software Production and Use: A Structurational Analysis. MIS Quarterly 26, 359-380 (2002)

6. Taylor, S., Todd, P.A.: Understanding Information Technology Usage: A Test of Competing Models. Information Systems Research 6, 144-176 (1995)

7. Boudreau, M.-C., Robey, D.: Enacting integrated information technology: A human agency perspective. Organization Science 16, 3-18 (2005)

8. Pedersen, P.E., Ling, R.: Modifying adoption research for mobile interent service adoption: Cross-disciplinary interactions. In: Proceedings of the 36th Hawaii International Conference on System Science. IEEE Computer Society, Washington (2003)

9. Scapens, R.W., Jazayeri, M.: ERP systems and management accounting change: opportunities or impacts? A research note. European Accounting Review 12, 201-233 (2003)

10. Granlund, M.: Extending AIS research to management accounting and control issues: A research note. International Journal of Accounting Information Systems 12, 3-19 (2011)

11. Elbashir, M.Z., Collier, P.A., Sutton, S.G.: The role of organisational absorptive capacity in strategic use of business intelligence to support integrated management control systems. The Accounting Review 86, 155-184 (2011)

12. Grabski, S.V., Leech, S.A., Schmidt, P.J.: A review of ERP research: A future agenda for accounting information systems. Journal of Information Systems 25, 37-78 (2011)

13. Dechow, N., Mouritsen, J.: Enterprise resource planning systems, management control and the quest for integration. Accounting, Organizations and Society 30, 691-733 (2005)

14. Quattrone, P., Hopper, T.: A 'time-space odyssey': management control systems in two multinational organisations. Accounting, Organizations and Society 30, 735-764 (2005)

15. Jack, L., Kholeif, A.: Enterprise Resource Planning and a contest to limit the role of management accountants: A strong structuration perspective. Accounting Forum 32, 30-45 (2008)

16. Booth, P., Matolcsy, Z., Wieder, B.: The impacts of enterprise resource planning systems on accounting practice - The Australian experience. Australian Accounting Review 10, 4-18 (2000) 
17. Hyvönen, T.: Management accounting and information systems: ERP versus BoB. European Accounting Review 12, 155-173 (2003)

18. Kallunki, J.P., Laitinen, E.K., Silvola, H.: Impact of enterprise resource planning systems on management control systems and firm performance. International Journal of Accounting Information Systems 12, 20-39 (2011)

19. Chapman, C.S., Kihn, L.A.: Information system integration, enabling control and performance. Accounting, Organizations and Society 34, 151-169 (2009)

20. Rom, A., Rohde, C.: Enterprise resource planning systems, strategic enterprise management systems and management accounting: A Danish study. Journal of Enterprise Information Management 19, 50-66 (2006)

21. Rom, A., Rohde, C.: Management accounting and integrated information systems: A literature review. International Journal of Accounting Information Systems 8, 40-68 (2007)

22. Davila, A., Foster, G.: Management control systems in early-stage startup companies. Accounting Review 82, 907-937 (2007)

23. Libby, T., Lindsay, R.M.: Beyond budgeting or budgeting reconsidered? A survey of North-American budgeting practice. Management Accounting Research 21, 56-75 (2010)

24. Abernethy, M.A., Brownell, P.: The role of budgets in organizations facing strategic change: an exploratory study. Accounting, Organizations and Society 24, 189-204 (1999)

25. Covaleski, M.A., Evans, H., Luft, J., Shields, M.: Budgeting reserach: Three theoretical perspectives and criteria for selective integration. In: Chapman, C., Hopwood, A., Shields, M. (eds.) Handbook of Management Accounting Reserach, vol. II, pp. 587-624. Elsevier, Oxford (2006)

26. Simons, R.: How New Top Managers Use Control Systems as Levers of Strategic Renewal. Strategic Management Journal 15, 169-189 (1994)

27. Frow, N., Marginson, D., Ogden, S.: Continuous budgeting: Reconciling budget flexibility with budgetary control. Accounting, Organizations and Society 35, 444-461 (2010)

28. Uppatumwichian, W.: Analysing Flexibility and Integration needs in budgeting IS technologies. In: The Twentith European Conference on Information Systems (2012)

29. Kallinikos, J.: Deconstructing information packages: Organizational and behavioural implications of ERP systems. Information Technology and People 17, 8-30 (2004)

30. Kumar, K., Van Hillegersberg, J.: ERP expiriences and evolution. Communications of the ACM 43, 22-26 (2000)

31. Dechow, N., Granlund, M., Mouritsen, J.: Management Control of the Complex Organization: Relationships between Management Accounting and Information Technology. In: Chapman, C., Hopwood, A., Shields, M. (eds.) Handbook of Management Accounting Research, pp. 625-640. Elsevier, Oxford (2007)

32. Granlund, M., Mouritsen, J.: Introduction: problematizing the relationship between management control and information technology. European Accounting Review 12, 77-83 (2003)

33. Light, B., Holland, C.P., Wills, K.: ERP and best of breed: a comparative analysis. Business Process Management Journal 7, 216-224 (2001)

34. Soh, C., Kien, S.S., Tay-Yap, J.: Cultural fits and misfits: Is ERP a universal solution? Communications of the ACM 43, 47-51 (2000)

35. Akkermans, H.A., Bogerd, P., Yücesan, E., van Wassenhove, L.N.: The impact of ERP on supply chain management: Exploratory findings from a European Delphi study. European Journal of Operational Research 146, 284-301 (2003) 
36. Strong, D.M., Volkoff, O.: Understanding organization-Enterprise system fit: A path to theorizing the information technology artifact. MIS Quarterly 34, 731-756 (2010)

37. Brazel, J.F., Dang, L.: The Effect of ERP System Implementations on the Management of Earnings and Earnings Release Dates. Journal of Information Systems 22, 1-21 (2008)

38. Spathis, C.: Enterprise systems implementation and accounting benefits. Journal of Enterprise Information Management 19, 67-82 (2006)

39. Cadili, S., Whitley, E.A.: On the interpretative flexibility of hosted ERP systems. The Journal of Strategic Information Systems 14, 167-195 (2005)

40. Häkkinen, L., Hilmola, O.-P.: Life after ERP implementation: Long-term development of user perceptions of system success in an after-sales environment. Journal of Enterprise Information Management 21, 285-310 (2008)

41. Quattrone, P., Hopper, T.: What is IT?: SAP, accounting, and visibility in a multinational organisation. Information and Organization 16, 212-250 (2006)

42. Daft, R.L., Lengel, R.H.: Organizational Information Requirements, Media Richness and Structural Design. Management Science 32, 554-571 (1986)

43. Fishbein, M., Ajzen, I.: Belief, attitude, intention and behaviour: An introduction to theory and research. Addison-Wesley, Reading (1975)

44. Drazin, R., Van de Ven, A.H.: Alternative Forms of Fit in Contingency Theory. Administrative Science Quarterly 30, 514-539 (1985)

45. Treviño, L.K., Webster, J., Stein, E.W.: Making Connections: Complementary Influences on Communication Media Choices, Attitudes, and Use. Organization Science 11, 163-182 (2000)

46. Robey, D., Boudreau, M.-C.: Accounting for the Contradictory Organizational Consequences of Information Technology: Theoretical Directions and Methodological Implications. Information System Research 10, 167-185 (1999)

47. Giddens, A.: Central problems in social theory. University of California Press, Barkeley (1979)

48. Poole, M.S., DeSanctis, G.: Structuration theory in information systems research: Methods and controversies. In: Whitman, M.E., Woszczynski, A.B. (eds.) The Handbook of Information Systems Research, pp. 206-249. Idea Group Publishing, Hershey (2004)

49. Walsham, G., Han, C.K.: Information systems strategy formation and implementation: The case of a central government agency. Accounting, Management and Information Technologies 3, 191-209 (1993)

50. Orlikowski, W.J.: The Duality of Technology: Rethinking the Concept of Technology in Organizations. Organization Science 3, 398-427 (1992)

51. Walsham, G.: Interpretive Case Studies in IS Research: Nature and Method. European Journal of Information Systems 4, 74-81 (1995)

52. Eisenhardt, K.M., Graebner, M.E.: Theory building from cases: Opportunities and challenges. Academy of Management Journal 50, 25-32 (2007)

53. Gerring, J.: What is a case study and what is it good for? American Political Science Review 98, 341-354 (2004)

54. Eisenhardt, K.M.: Building Theories from Case Study Research. The Academy of Management Review 14, 532-550 (1989)

55. Nicolaou, A.I.: Firm Performance Effects in Relation to the Implementation and Use of Enterprise Resource Planning Systems. Journal of Information Systems 18, 79-105 (2004)

56. Miles, M.B., Huberman, M.A.: Qualitative data analysis: an expanded sourcebook. Sage, Thousand Oaks (1994) 
57. Denzin, N.K.: The Reserach Act: A Theoretical Introduction to Sociological Methods. McGraw-Hill, New York (1978)

58. Ahrens, T., Chapman, C.S.: Accounting for flexibility and efficiency: A field study of management control systems in a restaurant chain. Contemporary Accounting Research 21, 271-301 (2004)

59. Chenhall, R.H.: Management control systems design within its organizational context: findings from contingency-based research and directions for the future. Accounting, Organizations and Society 28, 127-168 (2003)

60. Goodhue, D.L., Wybo, M.D., Kirsch, L.J.: The impact of data Integration on the costs and benefits of information systems. MIS Quarterly 16, 293-311 (1992)

61. Hyvönen, T., Järvinen, J., Pellinen, J.: A virtual integration-The management control system in a multinational enterprise. Management Accounting Research 19, 45-61 (2008)

\section{Appendix 1: Interview Guide}

How do you describe your business unit information?

What IS technologies are used in relation to budgeting procedure?

What are the budgeting procedures in your organisation?

What are the characteristics of pre-budget information gathering and analysis?

How does your business organisation prepare a budget?

How does your business organisation consolidate budget(s)?

How does your business organisation monitor budgets?

How does your business organisation prepare budget-related reports?

How does your organisation direct strategic management?

How does your organisation control normative management? 


\section{Appendix 2: Coding Example}

\begin{tabular}{|c|c|c|}
\hline Interview text & $\begin{array}{l}\text { Epic (underline) and } \\
\text { Emic (italic) Coding }\end{array}$ & $\begin{array}{l}\text { Themes emerging } \\
\text { from selective coding }\end{array}$ \\
\hline $\begin{array}{l}\text { Vice President of Information } \\
\text { Technology, Case I } \\
\text { SAP is too generic for } \\
\text { budgeting. From what I } \\
\text { understand I think SAP is } \\
\text { developing an industrial } \\
\text { product line but the budgeting } \\
\text { function is very small so they } \\
\text { think that it might not worth an } \\
\text { investment. First I think that is } \\
\text { why they brought in the BI. } \\
\text { Second, I think budgeting is } \\
\text { something for business } \\
\text { students. So they have to } \\
\text { develop something that } \\
\text { perfectly fits with the nature of } \\
\text { the business, but I know it is } \\
\text { not easy to do because they } \\
\text { have to deal with massive } \\
\text { accounting codes and a } \\
\text { complicated chart of accounts. }\end{array}$ & $\begin{array}{c}\frac{\text { Budget construction, }}{\text { ERP limitations }} \\
\text { Condition } \\
] \text { Consequences }\end{array}$ & $\begin{array}{l}\text { Comparing this } \\
\text { passage to other } \\
\text { passages } \\
\text { budgeting } \\
\text { construction, a theme } \\
\text { (ERP limitations) } \\
\text { emerges. Since } \\
\text { budgeting is a business } \\
\text { activity, ERP } \\
\text { developers must } \\
\text { develop software } \\
\text { which reflects the } \\
\text { business processes } \\
\text { (condition). Anyhow } \\
\text { this is not easy to do } \\
\text { because of the } \\
\text { complexity in real } \\
\text { business environments } \\
\text { (consequences), } \\
\text { therefore they just } \\
\text { develop a very generic } \\
\text { software } \\
\text { (consequences) } \\
\text { instead. }\end{array}$ \\
\hline
\end{tabular}

